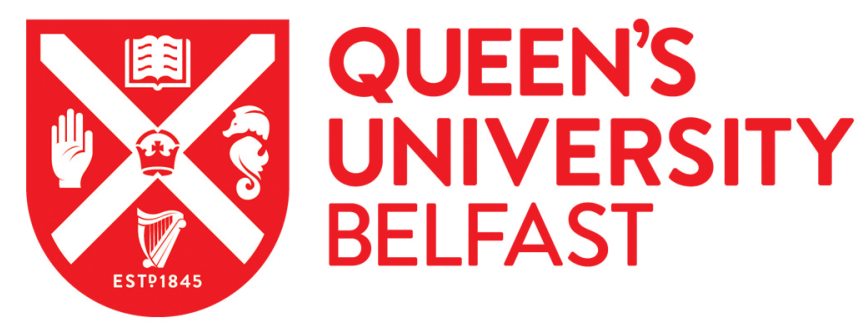

\title{
A successful comparison between a non-invasive measurement of local profiles during drying of a highly shrinkable food material (eggplant) and the spatial reaction engineering approach
}

Putranto, A., \& Chen, X. D. (2018). A successful comparison between a non-invasive measurement of local profiles during drying of a highly shrinkable food material (eggplant) and the spatial reaction engineering approach. Journal of Food Engineering, 235, 23-31. https://doi.org/10.1016/j.jfoodeng.2018.04.024

Published in:

Journal of Food Engineering

Document Version:

Peer reviewed version

Queen's University Belfast - Research Portal:

Link to publication record in Queen's University Belfast Research Portal

\section{Publisher rights}

Copyright 2018 Elsevier. This manuscript is distributed under a Creative Commons Attribution-NonCommercial-NoDerivs License (https://creativecommons.org/licenses/by-nc-nd/4.0/), which permits distribution and reproduction for non-commercial purposes, provided the author and source are cited.

\section{General rights}

Copyright for the publications made accessible via the Queen's University Belfast Research Portal is retained by the author(s) and / or other copyright owners and it is a condition of accessing these publications that users recognise and abide by the legal requirements associated with these rights.

Take down policy

The Research Portal is Queen's institutional repository that provides access to Queen's research output. Every effort has been made to ensure that content in the Research Portal does not infringe any person's rights, or applicable UK laws. If you discover content in the

Research Portal that you believe breaches copyright or violates any law, please contact openaccess@qub.ac.uk. 
A successful comparison between a non-invasive measurement of local profiles during drying of a highly shrinkable food material (eggplant) and the spatial reaction engineering approach

\section{(1)} (1)

Modeling local profiles inside of food materials by the spatial reaction engineering (1) (1)

7

8

$$
\text { approach }
$$

Abbreviated running title: 
A reliable mathematical model is useful for predicting the internal profiles inside the materials during drying.In this study, for the first time, the spatial reaction engineering approach (SREA) is used to model the local profiles of food materials during drying. The REA is applied as the local rate of phase change and combined with a set of equations of conservation of heat and mass transfer to yield the spatial temperature and concentration profiles during drying. The S-REA predictions are benchmarked against the Magnetic Resonance Imaging (MRI) data. The study indicates that the S-REA is applicable to model the internal profiles inside food materials during drying. The S-REA predictions also show closer agreement towards the experimental data than the effective diffusion model. While the S-REA predictions are accurate, it requires minimum number of experiments to generate the drying parameters. The S-REA has contributed to better analysis of transport phenomena inside food materials during drying through generation of local profiles. The S-REA predictions are useful to interpret the sensory and quality matters during drying such as hardness and crispiness. engineering approach

\section{Introduction}



to extend the shelf life and to minimise transportation costs (Chou et al., 2000). It is an energy intensive process since large amount of heat needs to be supplied for vaporising water. Drying

may also alter the product structure, impacting on the quality. For fruits and vegetables, drying may lead to non-enzymatic browning, loss of ascorbic acid, loss of beta carotene content, color changes and many other chemical changes (Pan et al., 1999; Cnossen et al., 2002).

Tailoring drying schemes and conditions are feasible to ensure good product quality is met. The internal profiles of moisture content and temperature along with the microstructures are essential information. This understanding is useful to systematically fine-tune the drying schemes. The ability to manage average moisture content and average temperature seems not sufficient these days. The antioxidant capacity, phenolic content, loss of vitamin $\mathrm{C}$ and color changes during drying of fruits and vegetables can be related to the local moisture content and the local temperature (Fan et al., 2017; Horuz et al., 2017). For rice, high temperature and moisture content gradients may induce fissuring and breakage. Drying under time-varying conditions has shown to minimise the fissuring since it allows the moisture and heat to equilibrate inside the samples (Aqueretta et al., 2007; Dong et al., 2010). In baking, the understanding of local variables assists in optimising crispness, softness and color changes due to browning reactions, starch gelatinisation and protein denaturation (Hadiyanto et al., 2008). Since evaporation/condensation occurs inside bread, the temperature gradients inside the samples need to be studied (De Vries et al., 1989).

Reliable drying models can be used assist in predicting the internal profiles during drying. For this purpose, the spatial drying models are useful. The diffusion-based models are commonly implemented to describe drying with a wide range of accuracy is shown (Vaquiro 
et al., 2009; Brasiello et al., 2013; 2017). Most of the models use the effective diffusivity to lump the capillary and water vapor diffusivity (Mariani et al., 2007; Vaquiro et al., 2009; Brasiello et al., 2011; 2017). In addition, Luikov's based models (Luikov, 1975) based on classical thermodynamics are used to represent the spatial profiles. The models postulate that the thermal and moisture potential gradient within a porous body cause the vapor and liquid water transfer so that the flux of liquid water and water vapor is proportional to the thermal gradient and moisture potential gradient. The two-way coupled system of Luikov's approach was implemented to model timber drying and a reasonable agreement towards the experimental data is shown (Thomas et al., 1980; Kulasiri and Samarasinghe, 1986). Similarly, Whitaker's approach (Whitaker, 1977) can be implemented to generate the spatial profiles during drying. Darcy's law is usually used to describe the momentum transfer in liquid and gas phases while the mass transfer considers capillary action as well as evaporation/condensation. This approach has been used to model several drying process well (Hager et al., 2000; Torres et al., 2011). model drying. The major physics of drying is captured by the relative activation energy of the REA. The relative activation energy is essentially material characteristics which describe the difficulty to remove moisture from materials being dried. At the beginning of drying, the relative activation energy is zero and it keeps increasing as drying progresses. When the equilibrium condition is achieved, the relative activation energy is one. The REA requires minimum number of experiments to generate the relative activation energy since the one generated from one accurate drying run is applicable to project drying the same materials at other conditions provided the similar initial moisture content (Chen and Putranto, 2013). When compared to characteristics drying rate curve (CDRC), the REA gives advantages in yielding natural transition during drying since it does not depend on the critical moisture content (Baini 
and Langrish, 2007). Therefore, it is applicable to describe the heat and mass transfer processes under time-varying conditions (Putranto et al, 2011 $1^{\mathrm{a}-\mathrm{c}}$ ). Benchmarks against diffusion-based models also showed that the REA result in closer agreement towards experimental data (Putranto and Chen, 2011 $1^{\mathrm{a}-\mathrm{b}}$ ).

The REA in its lumped format is further called as the lumped reaction engineering approach (L-REA) and it has been combined with a set of equations of conservation of heat and mass transfer to yield a spatial model labelled as the spatial reaction engineering approach (S-REA) (Chen and Putranto, 2013). The S-REA is non-equilibrium multiphase model in whichthe REA is used as the local evaporation/condensation rate. The use of non-equilibrium multiphase model is suggested as it is more general and can be used to assess the applicability of the equilibrium multiphase drying model (Zhang and Datta, 2004; Chen, 2007). It also yields better understanding of transport phenomena during drying since the profiles of concentration of water vapor can be established. In S-REA, the moisture content inside the solid matrix is not assumed to be in equilibrium with the concentration of water vapor inside pore spaces. The SREA has been used so far to describe a number of heat and mass transfer processes including convective drying, intermittent drying, baking and water vapor sorption (Putranto and Chen, $\left.2015^{\mathrm{a}-\mathrm{c}}\right)$. In these studies, the S-REA is shown to be able to model well the average moisture content.

However, it is not certain whether the S-REA can be used to model the internal profiles inside food materials during drying. In this study, for the first time, the S-REA is applied to model the local profiles during drying. The capability of the S-REA is tested by benchmarking the S-REA predictions against a set of Magnetic Resonance Imaging (MRI) data. The eggplant is chosen as a shrinkable vegetable that present reasonable challenges to model. The outline of 
this paper is as follows. The experimental details are reviewed briefly followed by the mathematical modelling using S-REA. The reported results of modelling are then discussed.

\section{Review of experimental details}

The experimental data for validating the results of modelling are derived from previous study (Brasiello et al., 2017). For better understanding of the modelling, the experimental details are reviewed briefly here. The fresh eggplant is firstly stored in the fridge at $4{ }^{\circ} \mathrm{C}$ before processing. The samples are then washed, cut longitudinally around the centre from left to right and shaped using a steel mould to give an initial diameter of $2 \mathrm{~cm}$. The samples are randomised before processing to avoid unavoidable difference in material structure. The initial sample moisture content is $12.75 \pm 0.96 \mathrm{~kg}$ water.kg dry solids ${ }^{-1}$ (Brasiello et al., 2017). Drying is conducted in a forced convective dryer (Espec Corp SU221) at drying air temperature of $50{ }^{\circ} \mathrm{C}$ and air velocity of $1.2 \mathrm{~m} \cdot \mathrm{s}^{-1}$. During drying, the weight loss is measured at particular timings using gravimetric method and the moisture content is analysed using the AOAC standards (Helrich, 1990). For the measurement of the internal moisture content distribution at different timings, Magnetic Resonance Imaging (MRI) is implemented (Brasiello et al., 2017).

\section{Mathematical modelling using the spatial reaction engineering approach (S-REA)}

The spatial reaction engineering approach (S-REA) is used to model the convective drying of eggplant in this study. The details of the reaction engineering approach (REA) have been published previously (Chen and Putranto, 2013; Putranto and Chen, 2015 ${ }^{\mathrm{a}, \mathrm{b}} ; 2016$; Putranto et al., 2017). The S-REA consists of a set of equations of conservation of heat and mass transfer in which the REA is used to describe the local evaporation rate. In S-REA, the moisture content inside the solid matrix is not assumed to be in equilibrium with the 
where $T$ is the sample temperature $(\mathrm{K}) . \rho$ is the sample density $\left(\mathrm{kg} \mathrm{m}^{-3}\right), C_{p}$ is the sample specific concentration of water vapor inside pore spaces. The REA serves as a source and depletion term for equation of conservation of water vapour and liquid water, respectively.

The mass balance of liquid water can be represented as (Chen and Putranto, 2013; Putranto and Chen, 2015 $\left.5^{\mathrm{a}-\mathrm{c}}\right)$ :

$$
\frac{\partial\left(C_{s} X\right)}{\partial t}=\frac{1}{r} \frac{\partial}{\partial r}\left(D_{w} r \frac{\partial\left(C_{s} X\right)}{\partial r}\right)-\dot{I}
$$

where $t$ is the time (s), $r$ is the sample radius $(\mathrm{m}), X$ is the concentration of liquid water $(\mathrm{kg}$ $\mathrm{H}_{2} \mathrm{O} \mathrm{kg}$ dry solids $\left.{ }^{-1}\right), D_{w}$ is the capillary diffusivity $\left(\mathrm{m}^{2} \mathrm{~s}^{-1}\right), C_{s}$ is the solids concentration $(\mathrm{kg}$ dry solids $\left.\mathrm{m}^{-3}\right), I$ is the local evaporation or condensation rate $\left(\mathrm{kgm}^{-3} \mathrm{~s}^{-1}\right)$ and $I$ is $>0$ when evaporation occurs locally.

The mass balance of water vapor can be written as (Chen and Putranto, 2013; Putranto and Chen, 2015 $\left.5^{\mathrm{a}-\mathrm{c}}\right)$ :

$$
\frac{\partial C_{v}}{\partial t}=\frac{1}{r} \frac{\partial}{\partial r}\left(D_{v} r \frac{\partial C_{v}}{\partial r}\right)+\dot{I}
$$

where $C_{v}$ is the concentration of water vapor $\left(\mathrm{kg} \mathrm{H}_{2} \mathrm{O} \mathrm{m}{ }^{-3}\right)$ and $D_{v}$ is the water vapor diffusivity $\left(\mathrm{m}^{2} \mathrm{~s}^{-1}\right)$.

In addition the heat balance can be represented as (Chen and Putranto, 2013; Putranto and Chen, 2015 $\left.5^{\mathrm{a}-\mathrm{c}}\right)$ :

$$
\rho C_{p} \frac{\partial T}{\partial t}=\frac{1}{r} \frac{\partial}{\partial r}\left(k r \frac{\partial T}{\partial r}\right)-\dot{I} \Delta H_{v}
$$

171 heat capacity $\left(\mathrm{J} \mathrm{kg}^{-1} \mathrm{~K}^{-1}\right), \Delta H_{\nu}$ is the water vaporization enthalpy $\left(\mathrm{J} \mathrm{kg}^{-1}\right)$ and $k$ is the sample 172 thermal conductivity $\left(\mathrm{W} \mathrm{m}^{-1} \mathrm{~K}^{-1}\right)$. 
174 The initial and boundary conditions of equations (1) to (3) are:

$175 t=0, X=X_{o}, C_{v}=C_{v o}, T=T_{o}$ (initial condition, uniform initial concentrations and temperature)

$177 \quad r=0, \frac{d X}{d r}=0, \frac{d C_{v}}{d r}=0, \frac{d T}{d r}=0 \quad$ (symmetrical condition)

$178 \quad r=R$,

$179-C_{s} D_{w} \frac{d X}{d r}=h_{m} \varepsilon_{w}\left(\frac{C_{v, s}}{\varepsilon}-\rho_{v, b}\right)$ (convective boundary for liquid water transfer)

180

where $\varepsilon_{w}$ is the fraction of surface area covered by liquid water.

$181-D_{v} \frac{d C_{v}}{d r}=h_{m} \varepsilon_{v}\left(\frac{C_{v, s}}{\varepsilon}-\rho_{v, b}\right)$ (convective boundary for water vapor transfer)

where $\varepsilon_{v}$ is the fraction of surface area covered by water vapor.

183

184

$k \frac{d T}{d r}=h\left(T_{b}-T\right) \quad$ (convective boundary for heat transfer)

$186 I$ is the local drying or wetting rate within the solid structure described as (Putranto and Chen, $\left.1872015^{\mathrm{a}-\mathrm{c}}\right)$

$$
\dot{I}=h_{m_{\text {in }}} A_{\text {in }}\left(C_{v, s}-C_{v}\right)
$$

189 where $h_{m, \text { in }}$ is the internal mass transfer coefficient $\left(\mathrm{m} \mathrm{s}^{-1}\right), A_{\text {in }}$ is the total internal surface area 190 available for phase change $\left(\mathrm{m}^{2} \mathrm{~m}^{-3}\right), C_{v, s}$ is the internal-solid-surface water vapor concentration $191\left(\mathrm{~kg} \mathrm{~m}^{-3}\right)$. 
193

By implementing the REA, internal-surface water vapor concentration can be written as (Chen and Putranto, 2013):

$$
C_{v, s}=\exp \left(\frac{-\Delta E_{v}}{R T}\right) C_{v, s a t}
$$

where $\Delta E_{v}$ is the activation energy $\left(\mathrm{J} \mathrm{mol}^{-1} \mathrm{~K}^{-1}\right)$ and $C_{v, \text { sat }}$ is the internal-saturated water vapour concentration $\left(\mathrm{kg} \mathrm{m}^{-3}\right)$

Therefore, the local drying or wetting rate can be expressed as (Chen and Putranto, 2013):

$$
\dot{I}=h_{m_{\text {in }}} A_{\text {in }}\left(\exp \left(\frac{-\Delta E_{v}}{R T}\right) C_{v, s a t}-C_{v}\right)
$$

The relative activation energy of convective drying of eggplant, as fingerprint of the REA, is established from eggplant drying at drying air temperature of $60{ }^{\circ} \mathrm{C}$ (Adiletta et al, 2014). Only one temperature data set is used to generate the relate activation energy function. Based on the experimental data set of drying at $60{ }^{\circ} \mathrm{C}$, the activation energy is calculated. Dividing the activation energy $\left(\Delta E_{v}\right)$ with the equilibrium activation energy $\left(\Delta E_{v, b}\right)$ yields the relative activation energy $\left(\Delta E_{v} / \Delta E_{v, b}\right)$. The detailed equations to evaluate the activation energy and equilibrium activation energy have been presented previously (Putranto and Chen, 2015 $5^{\text {s- }}$ $\left.{ }^{c}\right)$. The relationship between the relative activation energy and average moisture content can be represented by simplified mathematical equation obtained by least square method. The relative activation energy $\left(\Delta E_{v} / \Delta E_{v, b}\right)$ of eggplant during convective drying can be represented as:

$$
\frac{\Delta E_{v}}{\Delta E_{v, b}}=-7.69 \times 10^{-4}\left(\bar{X}-X_{b}\right)^{3}+2.32 \times 10^{-2}\left(\bar{X}-X_{b}\right)^{2}-2.48 \times 10^{-1}\left(\bar{X}-X_{b}\right)+1
$$

The good agreement between the fitted and experimental relative activation energy is shown by $R^{2}$ of 0.999 and plotted in Figure 1 . The format of equation (12) can be varied to be the best 
213 fit but in this case, equation (12) is sufficient to describe the relative activation energy of 214 eggplant.

For modelling using S-REA, equation (12) is implemented to describe the 'local'

217 relative activation energy by substituting the average moisture content $(\bar{X})$ with the local

218 moisture content $(X)$. This is to say that the kinetics obtained for average parameters can also

219 be used as the local kinetics. Combining the 'local' relative activation energy with the equilibrium activation energy results in the 'local' activation energy which represents the 'local' behavioural changes of eggplant as affected by the local variables and structures. The 'local' activation energy is then implemented to represent the local evaporation and condensation rate shown in equation (11). The determination of transport properties used in the modelling is presented in Appendix A while the calculation of internal surface area $\left(A_{\text {in }}\right)$ is shown in Appendix B.

\section{Results and Discussion}

Figure 2 indicates the average moisture content during drying modelled by the S-REA. A very good agreement with the experimental data is resulted by the modelling. It is further 


3

0

confirmed by $R^{2}$ of 0.999 . When benchmarking against the diffusion-based model (Brasiello et al., 2017), the S-REA results in closer agreement with experimental data. The diffusionbased model gives $R^{2}$ of 0.92 (Brasiello et al., 2017). This indicates that the S-REA describes accurately the average moisture content during drying. The applicability of the S-REA may be because the relative activation energy is accurate to represent the structural changes inside the eggplant samples during drying.

The distribution of moisture content inside the samples at drying time of 1800 s is shown in Figure 3. The S-REA predicts accurately the spatial profiles of moisture content at this initial drying period. At the sample edge, the moisture content is lower than that at the core since the moisture is transferred from the centre to the drying air via convection. This also indicates that the moisture migrates outwards during drying. Although the modelling implemented by Brasiello et al. (2017) represents the parabolic profiles, the other model seems to overestimate the drying rate.

For drying time of $3600 \mathrm{~s}$, the spatial profiles of moisture content inside the eggplant samples are represented in Figure 4. Similar to Figure 3, the S-REA predictions match well with the experimental data and confirmed by $R^{2}$ of 0.98 . As drying progresses, the moisture content at this drying period is lower than that at $3600 \mathrm{~s}$. Similar to the profiles at drying time of $1800 \mathrm{~s}$, the maximum moisture content is located at the centre of the eggplant samples. Both the MRI data and the S-REA show the similar behaviors. The other model (Brasiello et al., 2017) shows the lower predictions of the moisture content at this drying time.

Figure 5 shows the distribution of moisture content at drying time of $5400 \mathrm{~s}$. The SREA also represents accurately the internal profiles of moisture content at this drying period. 
262 Compared to the modelling by the other modelling, a better agreement towards the

263

264

265

266

267

268

269

270

271

272

273

274

275

276

277

278

279

280

281

282

283

284

285

286

experimental data is shown by the S-REA. Similar results are also found during drying at drying time of $7200 \mathrm{~s}$ as indicated in Figure 6. As drying progresses, the gradient of moisture content inside the eggplant samples decreases in line with the depletion of moisture inside the samples.

As a whole, the S-REA outlined in this paper has performed very well in predicting the local behaviour of moisture transfer. It is in fact quite precise, which is a nice surprise considering it is based on the lumped model to obtain the kinetics data. For better representation of transport processes inside the materials, the spatial concentration of water vapor during drying time is generated and shown in Figure 7. At the beginning of drying, the distribution of concentration of water vapor is not large but this increases until drying time of 8000 s. More plateau-like profiles are then observed in the later drying period. This seems to correspond well with a relatively uniform moisture content and temperature profiles. The maximum concentration of water vapor is attained at the sample core which may be due to the maximum local moisture content at this location. The water vapor at the sample core diffuses outwards during drying since the concentration of water vapor in the drying air is lower than that at the sample surface.

Figure 8 indicates the spatial profiles of the local evaporation rate during drying inside the eggplant samples. At the beginning of drying, the local evaporation rate seems to be relatively uniform although the moisture content at the sample core is higher. The initial porosity of the samples is 0.72 . As drying progresses, the local evaporation rate at the inner part becomes higher than that that at the outer part which may bedue to the higher local pore surface relative humidity at the inner part of the samples as shown in Figure 9. The higher 
moisture content at the core of the samples as indicated in Figure 2 to 5 seems to correspond to this condition. This also corresponds to the profiles of water vapour concentration as shown in Figure 7. Along drying, the local evaporation rate increases because of the increase of temperature. Nevertheless, this only lasts until drying time of $5000 \mathrm{~s}$. After this period, the moisture content inside the samples decreases and the equilibrium condition is approached. The gradient of local evaporation rate also decreases towards the end of drying. In agreement with this, as shown in Figure 10, the local pore surface relative humidity inside the samples decreases as drying progresses. It has been shown here that the REA serves well as the local evaporation rate.

The spatial temperature profiles during drying are shown in Figure 10. The sample temperature increases as moisture being reduced to approach to the drying air temperature. The temperature at the outer part of the eggplant sample is slightly higher than that at the sample core. This is reasonable since the sample receives heat from the surrounding and the heat is mostly used for vaporizing the moisture. Any heat left is then penetrated inwards via conduction to increase the sample temperature. Nevertheless, the gradient temperature inside the eggplant samples is essentially small which is also indicated by $\mathrm{Ch}_{-} \mathrm{Bi}$ (Chen and Peng, 2005) which is found to be about 0.002 . The low gradients of temperature during drying of food materials are also reported previously (Putranto and Chen, 2015 $5^{\mathrm{a}-\mathrm{c}}$; Putranto et al., 2017). As drying progresses, the temperature gradient actually decreases and no noticeable of temperature difference is observed at the end of drying. This is in line with plateau profiles of moisture content, concentration of water vapor and local evaporation rate at the end of drying as discussed above. No temperature profiles are published by the other model (Brasiello et al., 2017). 
In this study, the S-REA has been shown to be able to model the internal profiles of eggplant during drying. The capability is probably because of the accuracy of 'local' activation energy, resulted from combination of both 'local' relative and equilibrium activation energy. The 'local' activation energy seems to be flexible to represent the 'local' drying behaviours at micro-scale as affected by local structure and drying conditions. As the local evaporation rate, the REA is useful not only to link equations of conservation of liquid water and water vapor but also to interpret the complex interrelationships of moisture content, concentration of water vapor and temperature during drying. rate has also been plotted to provide an insight to the transport phenomena. The understanding

Since the S-REA is applicable to model the internal profiles of food materials during drying, the S-REA can be implemented to evaluate the local mechanical properties. These predictions are useful to interpret the sensory and quality matters such as hardness and crispiness. These sensory properties cannot yet be predicted even with the most comprehensive models (Wang et al., 2012; Kharaghani et al., 2013). In addition, it is interesting to see the SREA applications in predicting the local profiles of more challenging drying cases including intermittent drying, infrared-heating, microwave and ultrasonic-assisted drying.

\section{Conclusions}

In this study, for the first time, the S-REA is used to model the internal profiles inside food materials during drying. The REA is used as the local evaporation/condensation rate and coupled with a set of equations of conservation of heat and mass transfer. When benchmarked against the available MRI data, the S-REA shows excellent predictions. The local evaporation of local profiles during drying of food materials can be gained by the S-REA. The S-REA is 
readily implemented as a tool to analyse the transport phenomena inside food materials during drying. The S-REA framework can be used to fine-tune the drying schemes to yield food materials with the desirable product characteristics.

340

341

342

343

344

345

346

347

348

349

350

351

352

353

354

355

356

357

358

359

360

361

362

363

364

365

Nomenclatures

A

surface area of samples

internal surface area

$\left(\mathrm{m}^{2}\right)$

$A_{\text {in }}$

$A_{p}$

cell surface area

$\left(\mathrm{m}^{2} \mathrm{~m}^{-3}\right)$

$C_{p} \quad$ specific heat of sample

$C_{S} \quad$ solids concentration

$C_{v}$

$C_{v, s}$

$C_{v, s a t}$

$D_{v}$

$366 \quad D_{v, o}$

water vapor concentration

internal-surface vapor concentration

$\left(\mathrm{m}^{2}\right)$

$\left(\mathrm{J} \mathrm{kg}^{-1} \mathrm{~K}^{-1}\right)$

$\left(\mathrm{kg} \mathrm{m}^{-3}\right)$

$\left(\mathrm{kg} \mathrm{m}^{-3}\right)$

internal-saturated vapor concentration

$\left(\mathrm{kg} \mathrm{m}^{-3}\right)$

effective water vapor diffusivity

$\left(\mathrm{kg} \mathrm{m}^{-3}\right)$

water vapor diffusivity

$\left(\mathrm{m}^{2} \mathrm{~s}^{-1}\right)$

liquid diffusivity

$\left(\mathrm{m}^{2} \mathrm{~s}^{-1}\right)$

heat transfer coefficient

$368 h$

$D_{w}$ 


\begin{tabular}{|c|c|c|c|}
\hline 369 & $h_{m}$ & mass transfer coefficient & $\left(\mathrm{m} \mathrm{s}^{-1}\right)$ \\
\hline 370 & $h_{m, i n}$ & internal mass transfer coefficient & $\left(\mathrm{m} \mathrm{s}^{-1}\right)$ \\
\hline 371 & $I$ & local evaporation/condensation rate & $\left(\mathrm{kg} \mathrm{m}^{-3} \mathrm{~s}^{-1}\right)$ \\
\hline 372 & $k$ & thermal conductivity of sample & $\left(\mathrm{W} \mathrm{m} \mathrm{m}^{-1} \mathrm{~K}^{-1}\right)$ \\
\hline 373 & $m_{p}$ & dry mass of cell & $(\mathrm{kg})$ \\
\hline 374 & $m_{s}$ & dried mass sample of material & $(\mathrm{kg})$ \\
\hline 375 & $m_{w}$ & mass of liquid water & $(\mathrm{kg})$ \\
\hline 376 & $n$ & constant & \\
\hline 377 & $N$ & number of cell in samples & \\
\hline 378 & $n_{p}$ & number of cell per unit volume & $\left(\mathrm{m}^{-3}\right)$ \\
\hline 379 & $r$ & radial position & (m) \\
\hline 380 & $R H_{b}$ & relative humidity of drying air & \\
\hline 381 & $r_{p}$ & cell radius & (m) \\
\hline 382 & $T$ & sample temperature & $(\mathrm{K})$ \\
\hline 383 & $T_{S}$ & surface sample temperature & $(\mathrm{K})$ \\
\hline 384 & $t$ & time & $(\mathrm{s})$ \\
\hline 385 & $T_{b}$ & drying air temperature & $(\mathrm{K})$ \\
\hline 386 & $V$ & volume of sample & $\left(\mathrm{m}^{3}\right)$ \\
\hline 387 & $V_{0}$ & initial volume of sample & $\left(\mathrm{m}^{3}\right)$ \\
\hline 388 & $V_{p}$ & cell volume & $\left(\mathrm{m}^{3}\right)$ \\
\hline 389 & $v_{w}$ & mass fraction of water & \\
\hline 390 & $X$ & moisture content on dry basis & $\left(\mathrm{kg} \mathrm{kg}^{-1}\right)$ \\
\hline 391 & $\bar{X}$ & average moisture content on dry basis & $\left(\mathrm{kg} \mathrm{kg}^{-1}\right)$ \\
\hline 392 & $X_{b}$ & equilibrium moisture content on dry basis & $\left(\mathrm{kg} \mathrm{kg}^{-1}\right)$ \\
\hline 393 & $X_{o}$ & initial moisture content & $\left(\mathrm{kg} \mathrm{kg}^{-1}\right)$ \\
\hline 394 & $\Delta E_{v}$ & apparent activation energy & $\left(\mathrm{J} \mathrm{mol}^{-1}\right)$ \\
\hline 395 & $\Delta E_{v, b}$ & equilibrium activation energy & $\left(\mathrm{J} \mathrm{mol}^{-1}\right)$ \\
\hline 396 & $\Delta E_{v, / \Delta E_{v, b}}$ & relative activation energy & \\
\hline 397 & $\Delta H_{v}$ & vaporization enthalpy of water & $\left(\mathrm{J} \mathrm{kg}^{-1}\right)$ \\
\hline 398 & $\varepsilon$ & porosity & \\
\hline 399 & $\varepsilon_{w}$ & fraction of surface area covered by liquid water & \\
\hline 400 & $\varepsilon_{v}$ & fraction of surface area covered by water vapor & \\
\hline 401 & $\varepsilon_{o}$ & initial porosity & \\
\hline 402 & $\rho$ & sample density & $\left(\mathrm{kg} \cdot \mathrm{m}^{-3}\right)$ \\
\hline 403 & $\rho_{s}$ & density of solids & $\left(\mathrm{kg} \cdot \mathrm{m}^{-3}\right)$ \\
\hline 404 & $\rho_{v, b}$ & vapor concentration in drying medium & $\left(\mathrm{kg} \cdot \mathrm{m}^{-3}\right)$ \\
\hline 405 & $\rho_{v, s}$ & surface vapor concentration & $\left(\mathrm{kg} \cdot \mathrm{m}^{-3}\right)$ \\
\hline 406 & $\rho_{v, s a t}$ & saturated vapor concentration & $\left(\mathrm{kg} \mathrm{m}^{-3}\right)$ \\
\hline 407 & $\rho_{w}$ & density of water & $\left(\mathrm{kg} \mathrm{m}^{-3}\right)$ \\
\hline 408 & $\tau$ & turtuosity & \\
\hline \multicolumn{4}{|l|}{409} \\
\hline 410 & & & \\
\hline
\end{tabular}


432

433 Appendix A. The physical and transport properties used in the modeling

$434 \rho=670 \mathrm{~kg} \mathrm{~m}^{-3}$

435 where $\rho$ is the density of eggplant $\left(\mathrm{kg} \mathrm{m}^{-3}\right)$ (Llave et al, 2016).

$436 C_{p}=1470+2720 X$

437 where $C_{p}$ is the specific heat of eggplant $\left(\mathrm{J} \mathrm{kg}^{-1} \mathrm{~K}^{-1}\right)(\mathrm{Lamb}, 1976)$.

$438 \quad k=14.8+49.3 X$ 
439 where $k$ is the thermal conductivity of eggplant $\left(\mathrm{W} \mathrm{m}^{-1} \mathrm{~K}^{-1}\right)$ (Sweat, 1974).

$440 \quad D_{v}=D_{v_{o}} \frac{\varepsilon}{\tau}$

441 where $D_{v}$ is the effective water vapour diffusivity $\left(\mathrm{m}^{2} \mathrm{~s}^{-1}\right)$ (Bird et al, 2002).

$442 D_{v o}=2.09 \times 10^{-5}+2.137 \times 10^{-7}(T-273.15)$

443 where $D_{v o}$ is the vapour diffusivity $\left(\mathrm{m}^{2} \mathrm{~s}^{-1}\right)$ (Slattery and Bird, 1958).

$444 \tau=\varepsilon^{-n}$

445 where $\tau$ is the turtuosity, $\varepsilon$ is the porosity and $n$ is the value between 0 to 0.5 (Audu and Jeffreys, 446 1975).

$447 \quad C_{s}=\frac{1-\varepsilon}{\frac{1}{\rho_{s}}+\frac{X}{\rho_{w}}}$

448 where $C_{s}$ is the solid concentration $\left(\mathrm{kg} \mathrm{m}^{-3}\right), \rho_{s}$ is the solid density $\left(\mathrm{kg} \mathrm{m}^{-3}\right)$ and $\rho_{w}$ is the water 449 density (Putranto and Chen, 2015 ${ }^{\mathrm{a}-\mathrm{c}}$ ).

$450 \quad \varepsilon=1-\frac{V_{0}}{V}\left(1-\varepsilon_{0}\right)\left(\frac{\frac{\rho_{s}}{\rho_{w}} X+1}{1+\frac{\rho_{s}}{\rho_{w}} X_{0}}\right)$

451 where $\varepsilon$ is the porosity, $V_{1}$ is the sample volume $\left(\mathrm{m}^{3}\right), V_{0}$ is the initial sample volume $\left(\mathrm{m}^{3}\right)$ and

$452 X_{0}$ is the initial moisture content ( $\mathrm{kg}$ water $\mathrm{kg}$ dry solids $\mathrm{s}^{-1}$ ) (Madiouli et al, 2007).

$453 \quad \varepsilon_{w}=\frac{C_{s} X}{\rho_{w}}$

454 where $\varepsilon_{w}$ is the fraction of surface area covered by liquid water (Ousegui et al,, 2010). 
$455 \quad \varepsilon_{v}=\frac{C_{v}}{\rho_{v}}$

456 where $\varepsilon_{v}$ is the fraction of surface area covered by water vapour (Ousegui et al., 2010).

$457 D_{w}=1.05 \times 10^{-4} \exp \left(-\frac{3265.91}{T}\right)$

458 where $D_{w}$ is the capillary diffusivity $\left(\mathrm{m}^{2} \mathrm{~s}^{-1}\right)$ (Brasiello et al, 2017).

459

$R=R_{0}\left(0.1817+0.9185 \frac{X}{X_{0}}\right)^{0.5}$

460

where $R$ is the sample radius (m) and $R_{0}$ is the initial sample radius (m) (Adiletta et al, 2014).

461

462

463

464

465

466 Appendix B. Evaluation of internal surface area $\left(\boldsymbol{A}_{\text {in }}\right)$ (Kar and Chen, 2010; Putranto and

467 Chen, $2015^{\mathrm{a}-\mathrm{c}}$ )

$468 A_{p}=4 \pi r_{p}{ }^{2}$

469 where $A_{p}$ is the cell surface area $\left(\mathrm{m}^{2}\right)$ and $r_{p}$ is the cell diameter $(\mathrm{m})$.

$470 \quad V_{p}=\frac{4}{3} \pi r_{p}^{3}$

471 where $V_{p}$ is the cell volume $\left(\mathrm{m}^{3}\right)$

$472 \quad m_{p}=\rho_{p} V_{p}\left(1-v_{w}\right)$ 
473 where $m_{p}$ is the cell mass $(\mathrm{kg})$ and $v_{w}$ is the volume fraction of water

$474 \quad N=\frac{m_{s}}{m_{p}}$

475 where $N$ is the number cell in samples and $m_{s}$ is the dried mass of the samples $(\mathrm{kg})$

$476 \quad n_{p}=\frac{N}{V_{s}}$

477 where $n_{p}$ is the number of cell per unit volume and $V_{s}$ is the dried cell volume $\left(\mathrm{m}^{3}\right)$

$478 \quad A_{\text {in }}=n_{p} A_{p}$

479 where $A_{\text {in }}$ is the internal surface area $\left(\mathrm{m}^{2} \mathrm{~m}^{-3}\right)$

480

481

482

483

484

References

485

Adiletta, G., Iannone, G., Russo, P., Patimo, G., De Pasquale, S., Di Matteo, M., 2014.

486

487

488 Moisture migration by magnetic resonance imaging during eggplant drying: preliminary study. International Journal of Food Science and Technology 49, 26022609.

Aquerreta J., Iguaz A., Arroqui C., and Virseda P., 2007. Effect of high temperature drying and 490 tempering on rough rice quality. Journal of. Food Engineering 80, 611-918.

491

492

Baini, R., Langrish, T.A.G., 2007. Choosing an Audu, T.O.K., Jeffreys, G.V. The drying of drops of particulate slurries. Trans IChemE Part A. 1975; 53: 165-175. 
appropriate drying model for intermittent and continuous drying of bananas, Journal of Food Engineering 79, 30-343.

Baini, R., Langrish, T.A.G., 2007. Choosing an appropriate drying model for intermittent and continuous drying of bananas, Journal of Food Engineering 79, 30-343.

Bird, R. B., Stewart, W. E., and Lightfoot, E. N. 2002. Transport Phenomena, $2^{\text {nd }}$ international ed., John Wiley, New York.

Brasiello, A., Adiletta, G., Russo, P., Crescitelli, S., Albanese, D., Di Matteo, M., 2013. Mathematical model of eggplant drying: shrinkage effect. Journal of Food Engineering 114, 99-105.

Brasiello, A., Iannone, G, Adiletta, G., De Pasquale, S., Russo, P., Di Matteo, M., 2017. Mathematical model for dehydration and shrinkage: Prediction of eggplant's MRI spatial profiles. Journal of Food Engineering 203, 1-5.

Chen, X.D., 2007. Moisture diffusivity in food and biological materials. Drying Technology $25,1203-1213$.

Chen, X.D., Putranto, A., 2013. Modeling Drying Processes: A Reaction Engineering Approach. Cambridge University Press, U.K.

Chen, X.D, Peng, X.F., 2005. Modified Biot number in the context of air drying of small moist porous objects. Drying Technology 23, 83-103.

Chou, S.K., Chua, K.J., Mujumdar, A.S., Hawlader, M.N.A., Ho, J.C., 2000. On the intermittent drying of an agricultural product, TransIChemE Part C 78, 193-203.

Cnossen, A.G., Siebenmorgen, T.J., Yang, W., 2002. The glass transition temperature concept in rice drying and tempering: effect on drying rate. Trans. ASAE 45, 759-766

De Vries, U., Sluimer, P., Bloksma, A. H., 1989. A quantitative model for heat transport in dough and crumb during baking. In Cereal Science and Technology in Sweden, Proceedings of an International Symposium (pp. 174-188). Sweden: Lund University. 
Dong, R., Lu, Z., Liu, Z., Nishiyama, Y., Cao, W., 2009. Moisture distribution in a rice kernel during tempering drying, J. Food Eng. 91, 126-132.

Hadiyanto, D.C. Esveld, R.M. Boom, G. van Straten, A.J.B. van Boxtel, 2008. Product quality driven design of bakery opertions using dynamic optimization. Journal of Food Engineering 86, 399-413.

Helrich, K., 1990. Official Methods of Analysis of AOAC International, fifteenth ed.Association of Official Analytical Chemists, Inc., Arlington, Virginia, USA.

Hager, J., Wimmerstedt, R., Whitaker, S., 2000. Steam drying a bed of porous spheres: Theory and experiment, Chemical Engineering Science 55, 1675-1698.

Kar, S., Chen, X.D., 2010. Moisture transport across porcine skin: experiments and implementation of diffusion-based models, International Journal of Healthcare Technology and Management 11, 474-522.

Kharaghani, A., Kirsch, C., Metzger, T., Tsotsas, E., 2013. Micro-scale fluid model for drying of highly porous aggregates. Computers and Chemical Engineering 52, 46-54.

Kulasiri, D., Samarasinghe, S., 1996. Modeling of heat and mass transfer of biological materials: a simplified approach of materials with small dimension. Ecological Modeling 86, 163-167.

Lamb, J., 1976. Influence of water on the thermal properties of foods. Chemical Industries 24, 1046-1048.

Llave, Y., Takemori, K., Fukuoka, M., Takemori, T., Tomita, H., Sakai, N., 2016..Mathematical modeling of shrinkage deformation in eggplantundergoing simultaneous heat and mass transfer during convectionovenroasting. Journal of Food Engineering 178, 124-136.

Luikov, A.V., 1975. Systems of differential equations of heat and mass transfer in capillaryporous bodies. International Journal of Heat and Mass Transfer 18, 1-14. 
Madiouli, J., Lecomte, D., Nganya, T., Chavez, S., Sghaier, J., Sammouda, H., 2007. A method for determination of porosity change from shrinkage curves of deformable Materials, Drying Technology 25, 621-628.

Mariani, V.C., de Lima, A.G.B., Coelho, L.S.. 2008. Apparent thermal diffusivity estimation of the banana during drying using inverse method. Journal of Food Engineering 85, $569-579$.

Ousegui, A., Moresoli, C., Dostie, M., Marcos, B., 2010. Porous multiphase approach for baking process - Explicit formulation of evaporation rate, Journal of Food Engineering $100,535-544$.

Pan, Y.K., Zhao, L.J., Dong, Z.X., Mujumdar, A.S., Kudra, T., 1999. Intermittent drying of carrot in a vibrated fluid bed: effect on product quality. Drying Technology 17, 2323 2340.

Putranto, A, Chen, X.D., Xiao, Z., Webley, P.A., 2011 $1^{\text {b }}$ Intermittent drying of mango tissues: implementation of the reaction engineering approach (REA). Industrial Engineering Chemistry Research 50, 1089-1098.

Putranto, A., Chen, X.D., 2015 . An assessment on modeling drying processes: Equilibrium multiphase model and the spatial reaction engineering approach. Chemical Engineering Research and Design 94, 660-672.

Putranto, A., Chen, X.D., 2015 . Bread baking and its color kinetics modeled by the spatial reaction engineering approach (S-REA). Food Research International 71, 58-67.

Putranto, A., Chen, X.D., 2015 . Spatial reaction engineering approach (S-REA): an effective approach to model drying, baking and water vapor sorption process. Chemical Engineering Research and Design101, 135-145.

Putranto, A., Chen, X.D., 2016. Drying of a system of multiple solvents: modeling by the reaction engineering approach (REA). AIChE Journal62, 2144-2153. 
Putranto, A., Chen, X.D., Webley, P.A., 2011 a , Modeling of drying of thick samples of mango and apple tissues using the reaction engineering approach (REA). Drying Technology 29, 961-973.

Putranto, A., Chen, X.D., Zhou, W., 2011 ${ }^{\mathrm{c}}$. Modeling of baking of cake using the reaction engineering approach (REA), Journal of Food Engineering 105, 306-311.

Putranto, A., Foerster, M., Woo., M.W., Chen, X.D., Selomulya, C., 2017. A continuumapproach modelling of surface composition and ternary component distribution inside low fat milk emulsions during single droplet drying. AIChE Journal 63, 2535-2545.

Slattery, J.C., Bird, R.B. 1958. Calculation of the diffusion coefficient of dilute gases and of the self diffusion coefficient of dense gases. AIChE Journal 4, 137-142.

Sweat, V.E., 1974. Experimental values of thermal conductivity of selected fruits and vegetables. Journal of Food Science 39, 1080-1083.

Thomas, H.R., Morgan, K., Lewis, R.W., 1980. A fully nonlinear analysis of heat and mass transfer problems in porous bodies, International Journal of Numerical Methods Engineering 15, 1381-1393.

Torres, S.S., Jomaa, W., Puiggali, J.R., Avramidis, S., 2011. Multiphysicsmodeling of vacuum drying of wood. Applied Mathematical Modelling 35, 5006-5016.

Wang, Y.J., Kharaghani, A., Metzger, T., Tsotsas, E., 2012. Pore network drying model for particle aggregates: assessment by X-ray microtomography. Drying Technology 30, 1800-1809.

Vaquiro, H.A., Clemente, G., Garcia Perez, J.V., Mulet, A., Bon, J., 2009. Enthalpy driven optimization of intermittent drying of Mangiferaindica L., Chemical Engineering Research and Design 87, 885-898.

Zhang, J., Datta, A.K., 2004. Some considerations in modeling of moisture transport in heating of hygroscopic materials. Drying Technology 22, 1983-2008. 


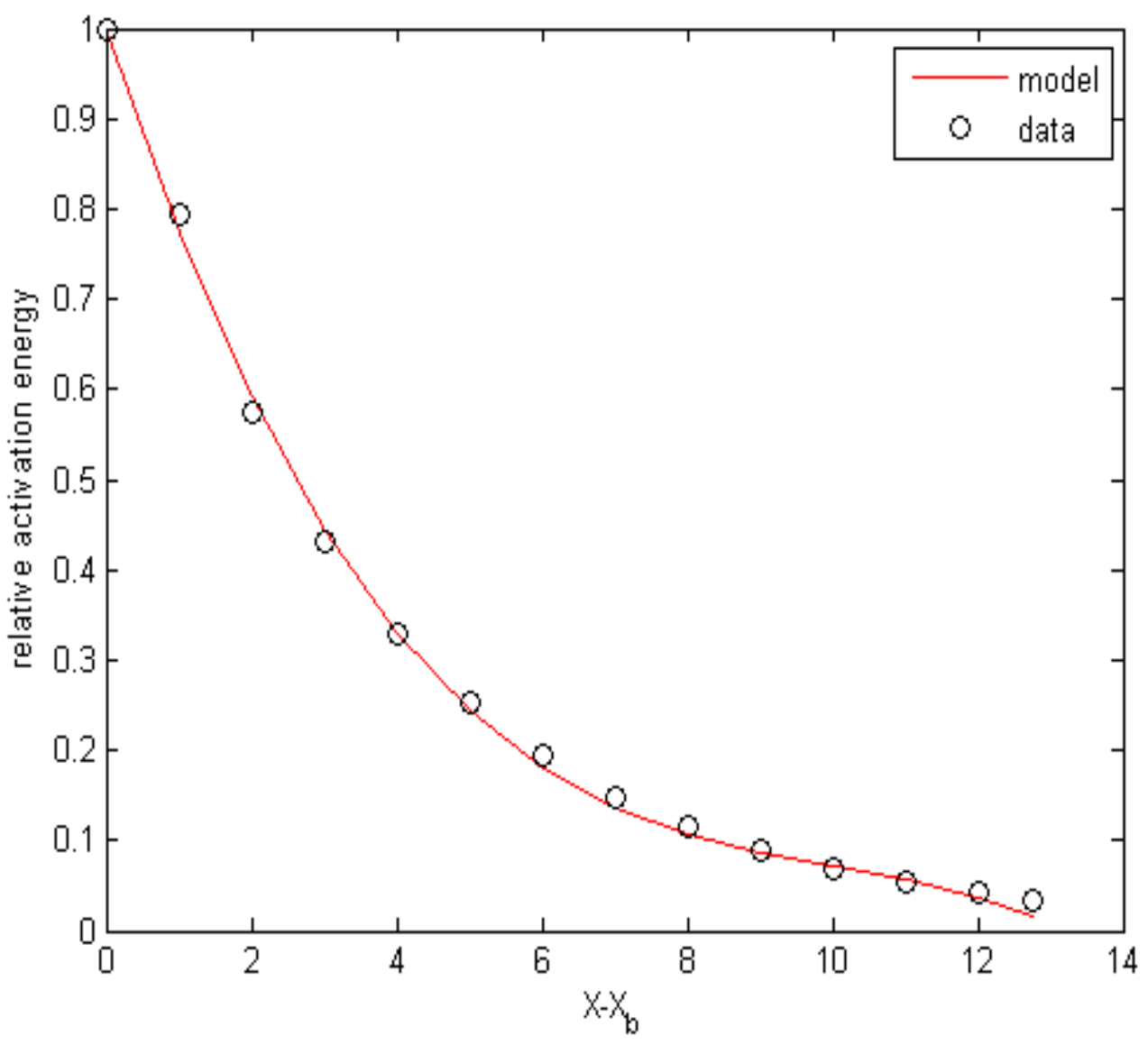

604 
605

606

607

608

609

610

611

612

613

614

615

616

617

618

619

620

Figure 1. The relative activation energy of eggplant during convective drying at drying air temperature of $60^{\circ} \mathrm{C}$

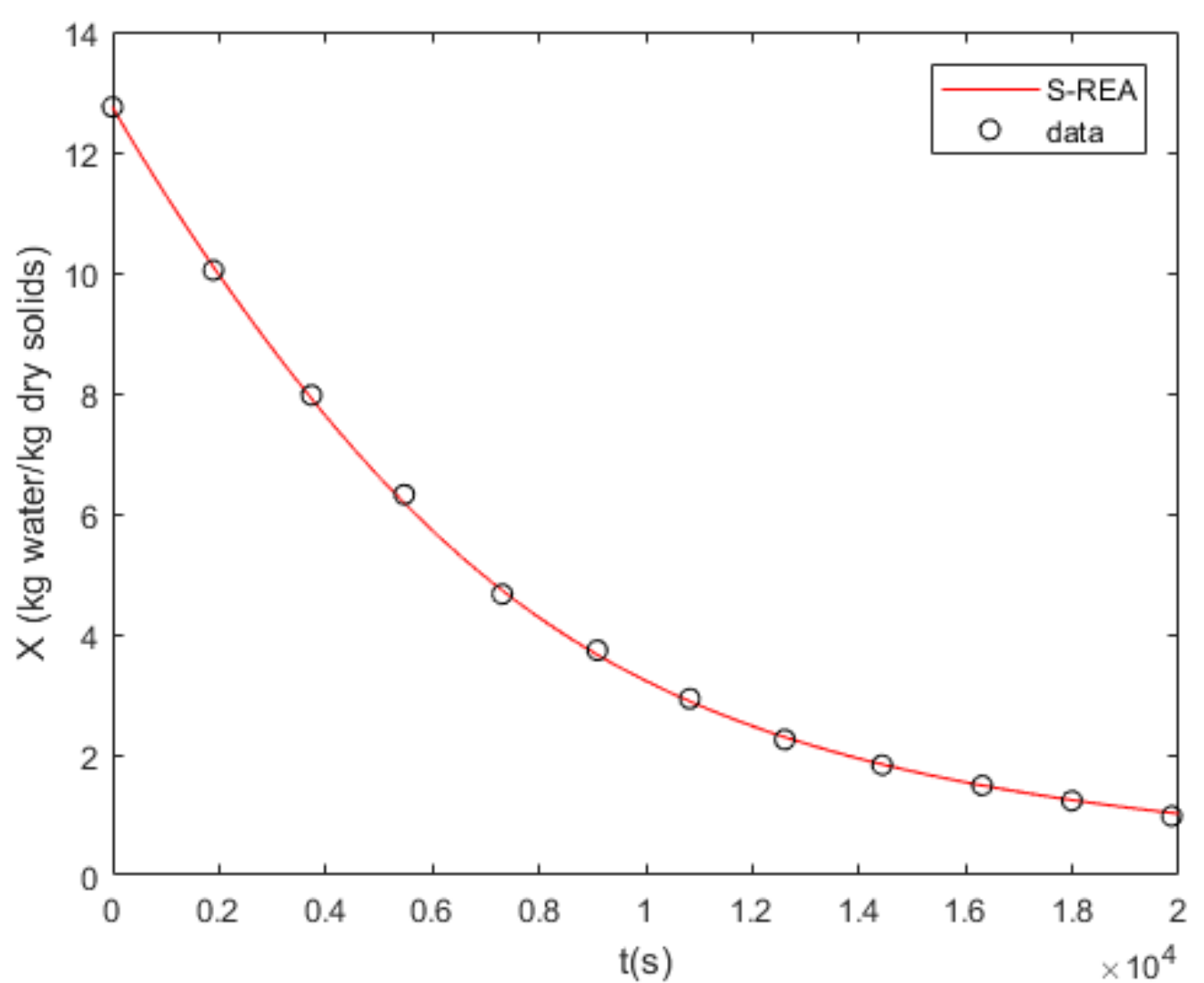

Figure 2. The average moisture content during convective drying at drying air 


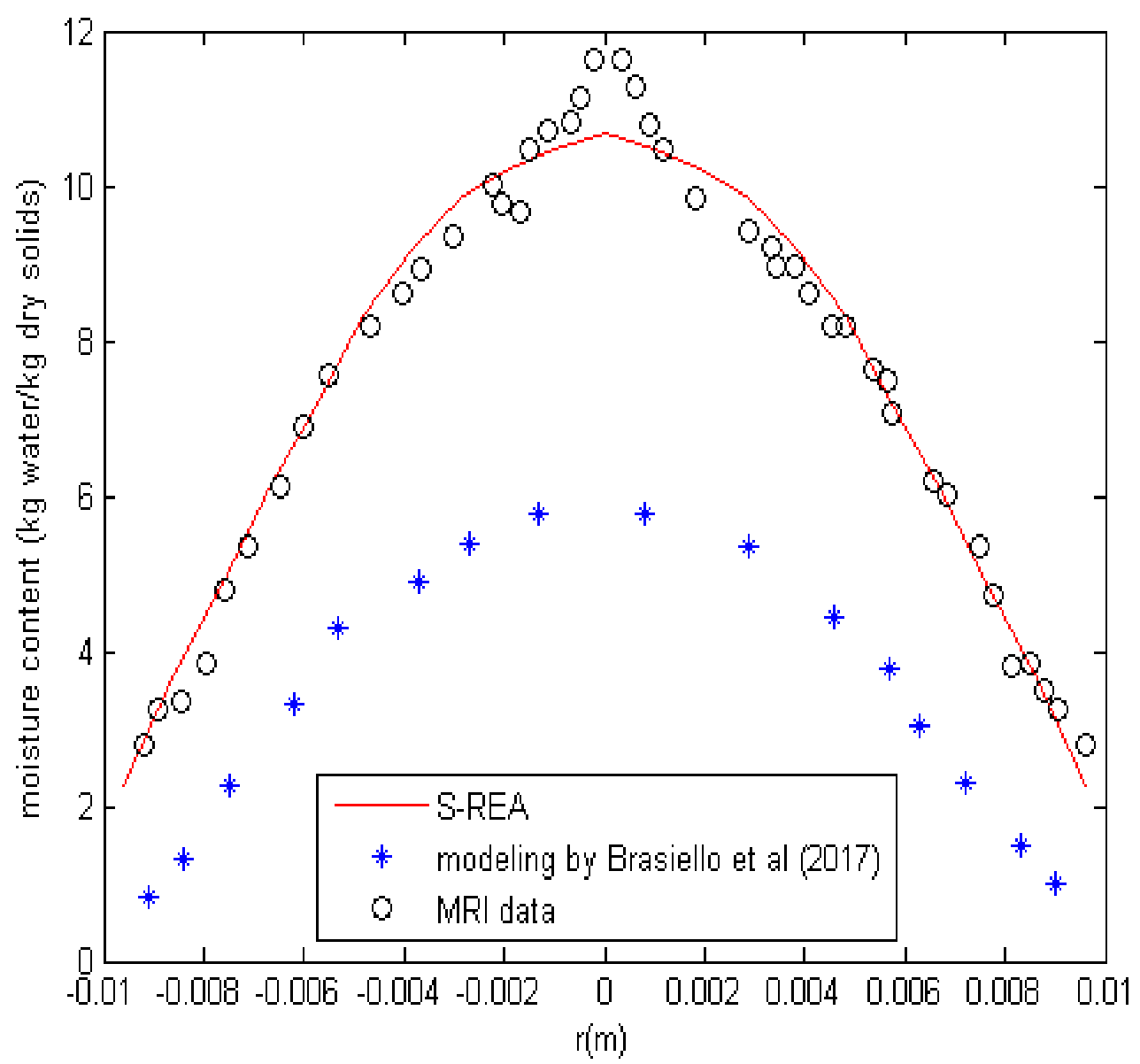




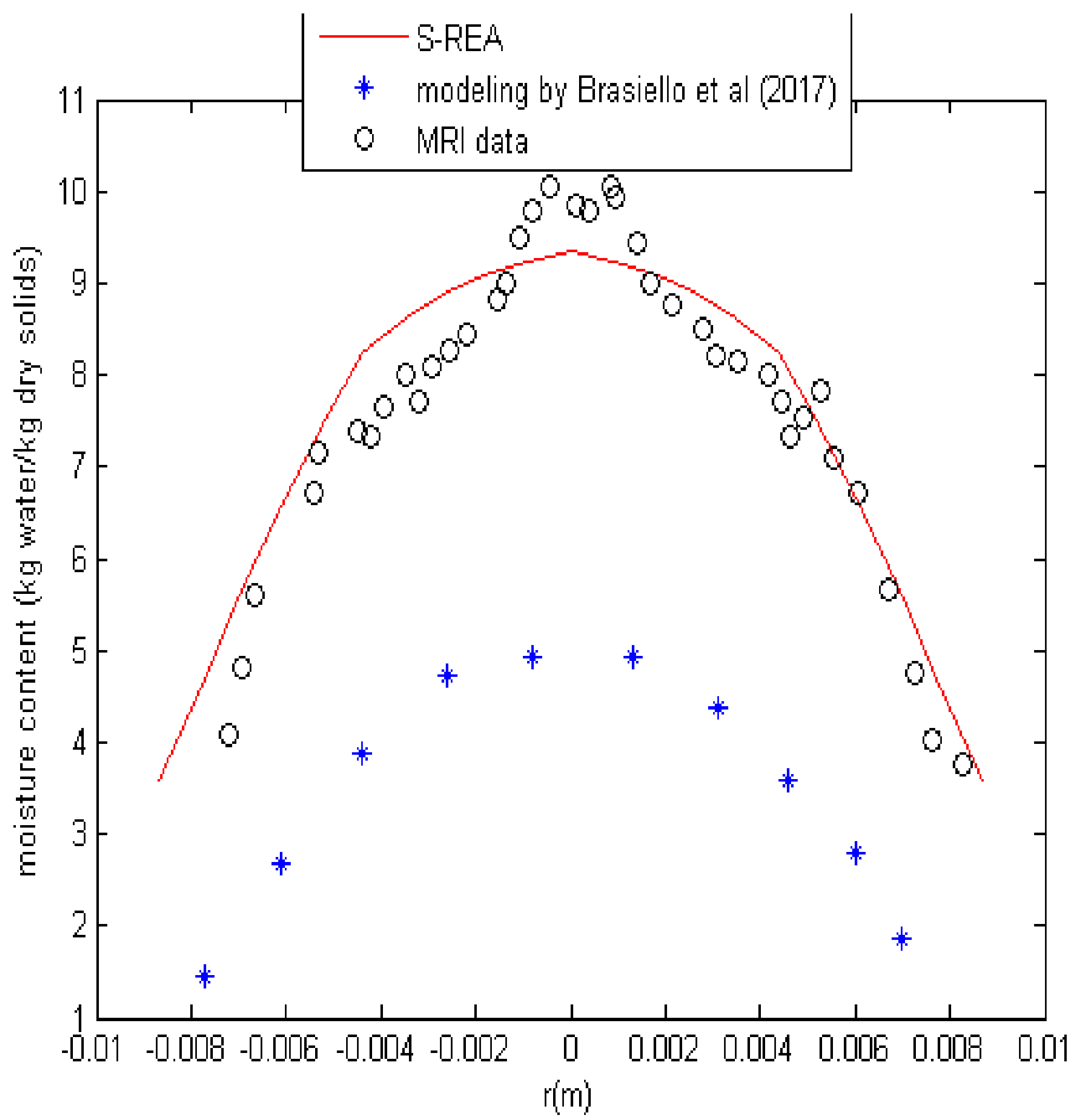


679

680

681

682

683

684

685

686

687

688

689

690

691

692

693

694

695

696

697

698

699

700

701
Figure 4. The internal moisture content profiles during convective drying of eggplant at drying time of $3600 \mathrm{~s}$ 


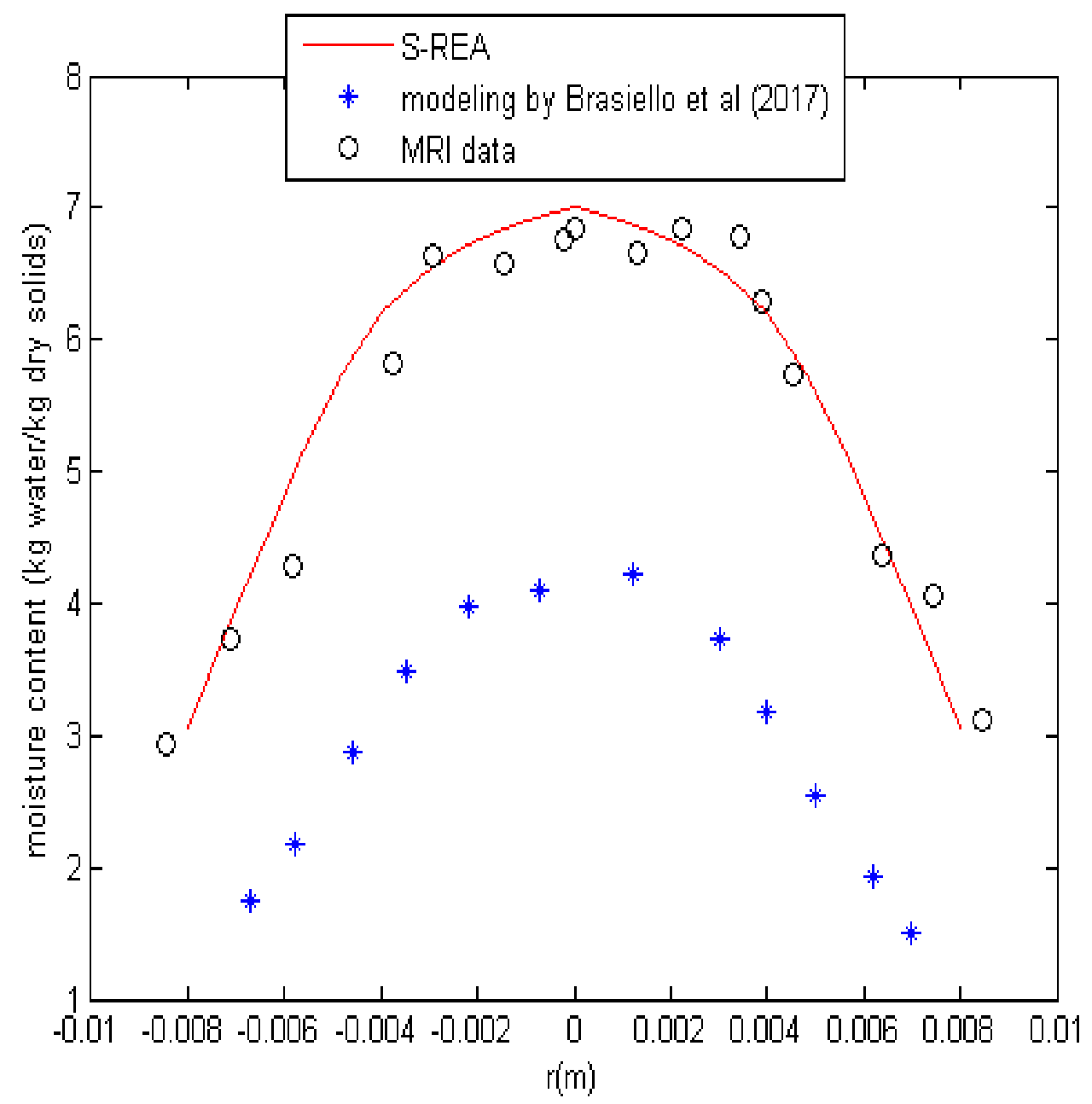

Figure 5. The internal moisture content profiles during convective drying of eggplant at drying time of $5400 \mathrm{~s}$ 


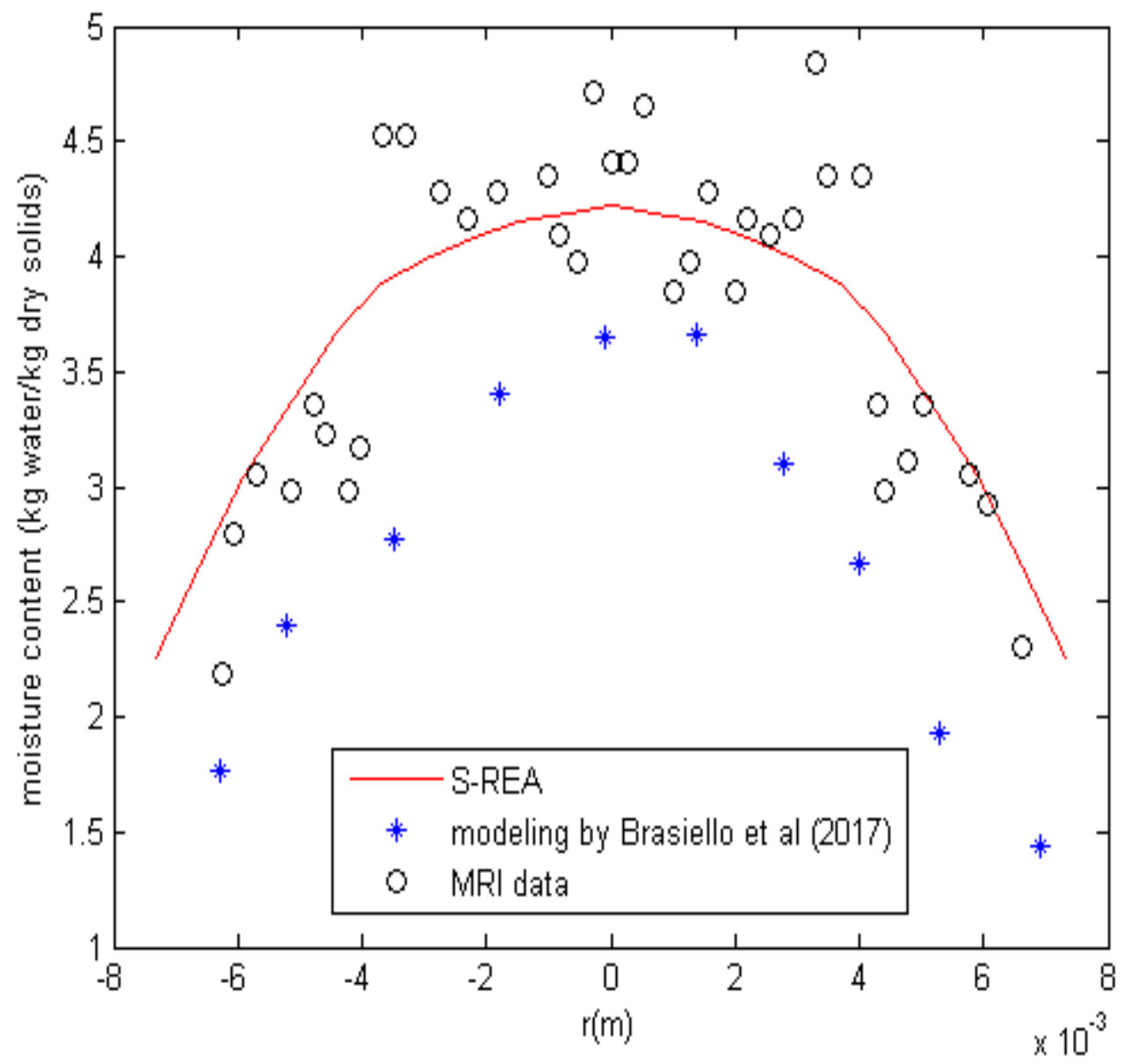

Figure 6. The internal moisture content profiles during convective drying of eggplant at drying time of $7200 \mathrm{~s}$ 


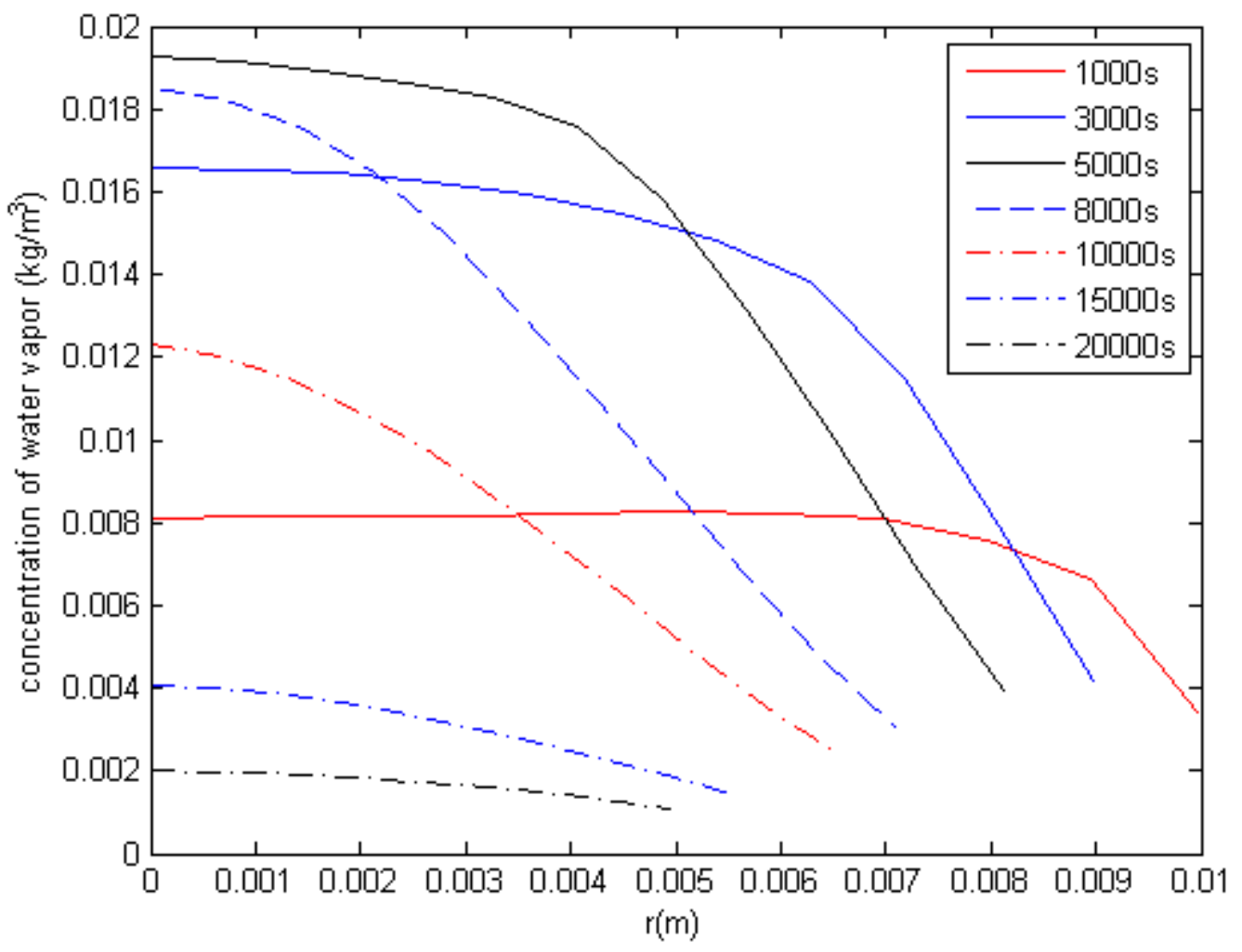

Figure 7. The spatial profiles of concentration of water vapor during convective drying of eggplant at drying air temperature of $50{ }^{\circ} \mathrm{C}$ 


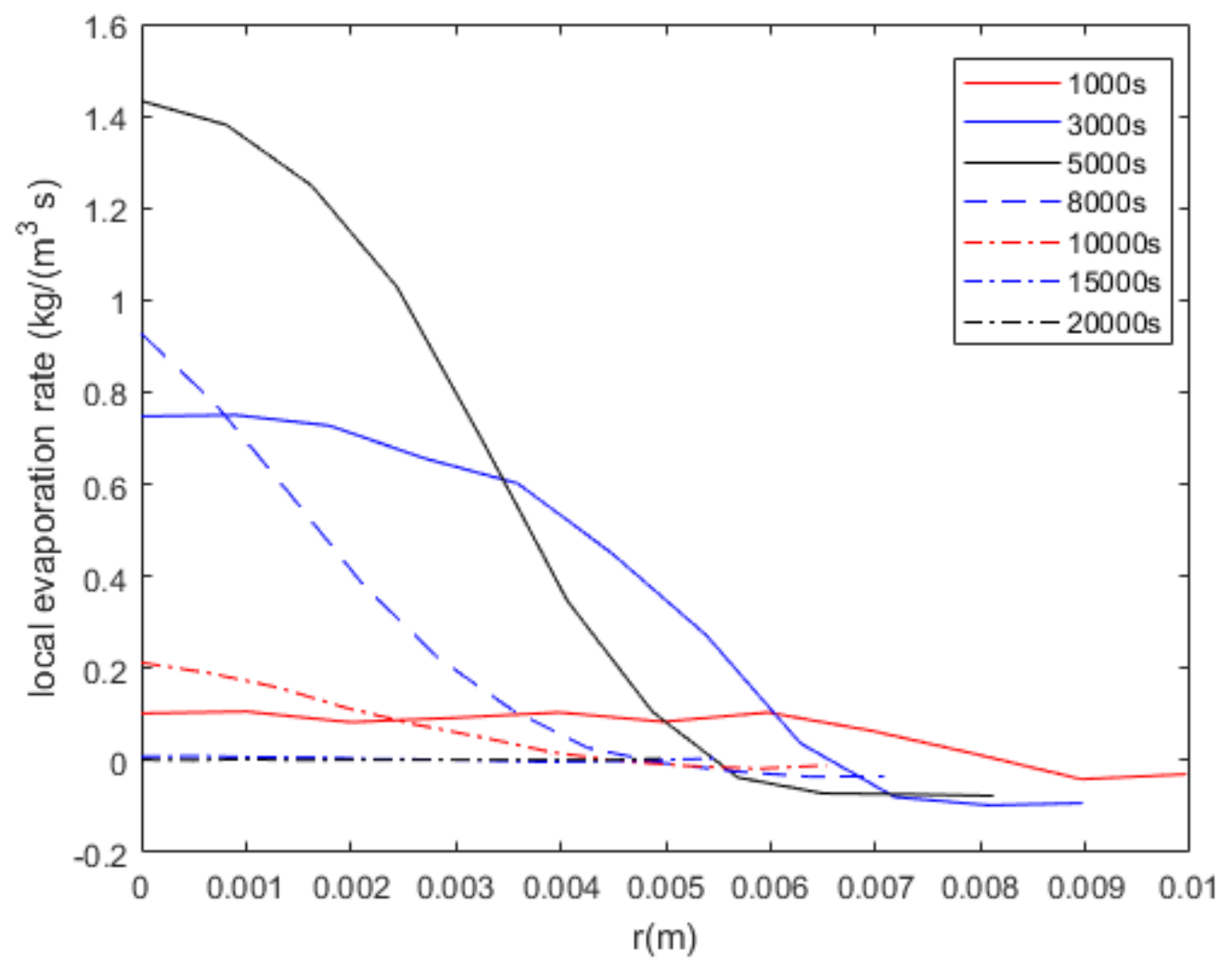

755

756

757

758

Figure 8. The spatial profiles of local evaporation rate convective drying of eggplant at drying air temperature of $50{ }^{\circ} \mathrm{C}$

759

760

761

762

763

764

765

766

767

768 


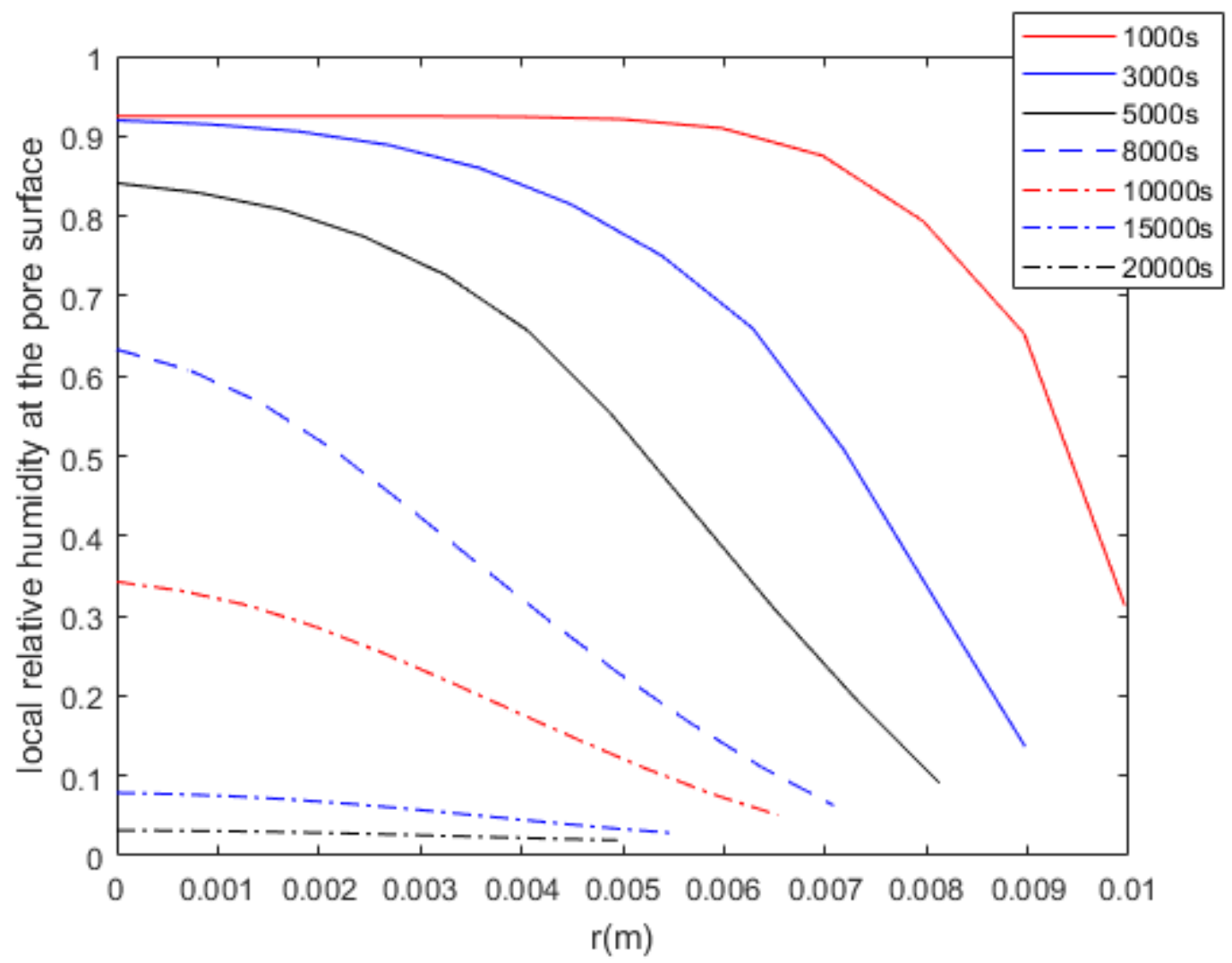

Figure 9. The spatial profiles of local pore surface relative humidity during convective drying of eggplant at drying air temperature of $50^{\circ} \mathrm{C}$ 


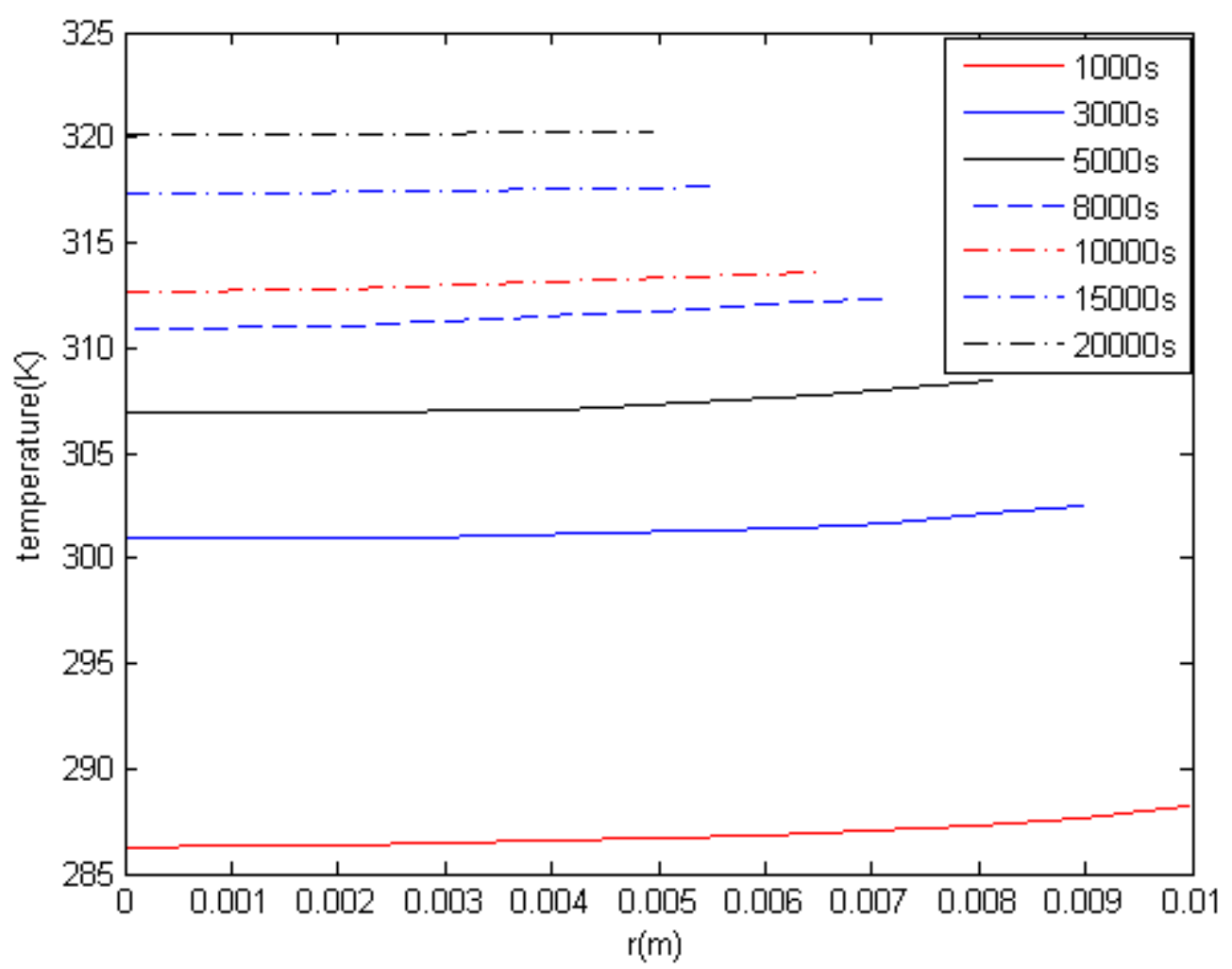

Figure 10. The spatial profiles of temperature during convective drying of eggplant at 791 drying air temperature of $50{ }^{\circ} \mathrm{C}$ 